\title{
Students' Attitudes towards Learning English in the Kurdistan region of Iraq
}

\author{
Shahla Ali Ahmed ${ }^{1}$, Baban Jabbar Othman ${ }^{2}$, Bayar Gardi ${ }^{3}$, Bawan Yassin Sabir ${ }^{4}$, \\ Nechirwan Burhan Ismael ${ }^{5}$, Pshdar Abdalla Hamza ${ }^{6}$, Sarhang Sorguli ${ }^{7}$, Hassan Mahmood \\ Aziz $^{8}$, Bayad Jamal Ali ${ }^{9}$, Govand Anwar ${ }^{10}$
}

\footnotetext{
${ }^{1}$ Department of Guidance and Psychological Counseling, Atatürk Faculty of Education, Near East University, Turkey

${ }^{2,3,4,7}$ Department of Accounting, College of Administration and Financial Sciences, Knowledge University, Kirkuk Road, 44001 Erbil, Kurdistan Region, Iraq.

${ }^{5}$ Department of Accounting, Cihan University - Duhok, Kurdistan Region, Iraq.

${ }^{6}$ Department of Business Administration, Kurdistan Technical Institute, Sulaymaniyah, Iraq. Email

${ }^{8}$ Department of Accounting and Finance, Faculty of Economics and Administrative Sciences, Cyprus International University, Mersin 10, Haspolat 99040, Cyprus.22010635@ student.ciu.edu.tr

${ }^{9}$ Business Administration Department, Komar University of Science and Technology, Sulaimani 46001, Kurdistan Region - Iraq ${ }^{10}$ Department of Business Administration, College of Administration and Financial Sciences, Knowledge University,44001 Erbil, Kurdistan Region, Iraq
}

Received: 07 Mar 2021; Received in revised form: 19 Apr 2021; Accepted: 02 May 2021; Available online: 20 May 2021 (C)2021 The Author(s). Published by Infogain Publication. This is an open access article under the CC BY license (https://creativecommons.org/licenses/by/4.0/).

\begin{abstract}
This research investigates students' attitudes towards learning English in Private Universities. Attitude is considered as a necessary component in language learning. Therefore, a positive attitude is considered as one of the important factors that have an impact on language learning. By providing insight into the attitudes of Private Universities students towards learning English, it contributes to the teaching of English as a foreign language. The main purpose of this research is to reveal students' attitudes towards learning English and find out how to make their attitudes positive. Language educators who know how to develop positive attitudes in students will be able to conduct interesting and effective classroom activities; get them to be more successful in learning English. The researcher points out that the main problem is the fact that students in Private Universities are not encouraged to English. This is one of the reasons why they have negative attitudes towards learning English. Students have a perception that they are forced to learn English. This causes them to be unwilling to learn English and develop target language skills. The researcher made use a questionnaire to obtain data about the learners' attitudes and analyse them. The random sampling technique was used. All the first-and second-year students at English department of the college in Private Universities were selected randomly for the study. The English department had 214 first-and secondyear students. The study revealed the fact that students have negative attitudes towards learning English in terms of emotional, behavioural and cognitive aspects. Thus, the first hypothesis is supported. As there is a statistically significant difference in Private Universities students' attitudes towards learning English language by gender, the second hypothesis is supported. The third hypothesis is supported by the fact that there is a statistically significant difference in Private Universities students' attitudes towards learning English language according to the duration of the study. According to the correlation test, the researcher came to the conclusion that there is correlation between three attitude factors: cognitive, behavioural and emotional. According to the correlation test, the researcher found out that cognitive has negative correlation ( $\left.r=.-.249^{* *}, p<0.01\right)$ with Behaviour. Concerning the negative of the linear relationship is moderately strong between cognitive and behaviour, cognitive has negative correlation ( $\left.r=.-.330^{* *}, p<0.01\right)$ with Emotional.
\end{abstract}


The negative of the linear relationship is moderately strong between cognitive and Emotional, and Behavioural has negative correlation $\left(r=.-.336^{* *}, p<0.01\right)$ with Emotional. The negative of the linear relationship is moderately strong between Emotional and behaviour, therefore hypotheses four supported. Concerning the experimental negative attitude towards learning English, the university lecturers are recommended to establish a motivating feeling in the English lessons to promote the students' positive attitudes towards learning English. Lecturers also should highlight the significance of learning English.

Keywords - Students' attitude, Personality, Learning English, Higher Education.

\section{INTRODUCTION}

Education is considered to be a powerful method which aids to change the behaviour of the students based on their needs and expectation of the society. Student attitude is considered an essential part of learning; consequently, it becomes an important element of second language learning. English language has an important role in many societies as it is the language which separates influential class from the rest of individual who lives in society (Abdullah \& Othman, 2019). According to Anwar \& Abdullah, (2021), concerning Individual's attitudes towards the learning English language, they state that it is the learning context that might explain their success in learning a language. Many lecturers have different strategies used in their class in order to recognize the target students' attitudes (Gardi et al. 2020) attitudes towards a specific language could be either positive or negative. Attitudes towards learning English language have an impact on behaviours such as choosing and reading books, listening to English radio, watching English channels etc. Particularly in academic, in case a student has a positive attitude towards learning English language, they will be able to attain many things in that particular area (Prabhu et al. 2020).

Many students begin learning English from primary school; some others from kindergarten or even from day care; however, the issue is that many of them are not able to accomplish the desired level of English proficiency, the main reason is de-motivation of students in all levels (Anwar \& Shukur, 2015). 'Attitude' is as somebody's thoughts or emotional state regarding to something, particularly as exposed in their behaviour. Section two of this research consists of Literature Review that will look into various studies, theories, attitude definitions, importance of attitudes and attitude components. Learning a new language is the powerful instrument which aids to adjust the behaviour of the student with regard to their desires and expectation of the society (Sultan et al. 2020). Student's attitude is an essential portion of learning; consequently, attitude is considered a vital factor of language learning (Abdullah \& Othman, 2015). Attitude towards learning English is supposed to affect attitude for instance choosing and reading the right material, communicating with a native English speaker and so on
(Top \& Ali, 2021). Particularly in University, if students have a positive attitude towards a particular topic, they will be able to attain numerous things in that particular field. There is a relation between learning language and the environmental mechanisms in which the students were grown up (Demir et al. 2020). Both positive and negative attitudes will have a huge influence on the achievement of learning the English language. According to Gardi, (2021), several factors that have impact on learning the English language process for instance, attitude, age, anxiety, aptitudes, gender, personality and so on ((Ismael et al. 2021). Anwar \& Abd Zebari, (2015) argue that learning a new language could aid students in demonstrating their idea, thoughts and opinion. This research concentrates on the idea of attitude as the main affective aspects for achievements in learning a new language (Ali, 2021). In more detail, it examines Private Universities students' attitudes towards learning English language, focusing on three aspects of attitude (emotional, behavioural and cognitive). Furthermore, it attempts to define the effect of students' demographic profile for instance, gender, field and year of study on attitudes towards learning English.

\section{Research Objectives}

The main objectives to examine Private Universities students' attitudes towards English language learning are;

1. To examine Private Universities students' attitudes towards learning English.

2. To figure out students' perceptions towards the learning of the literature component in the English language.

3. To investigate the attitudes of Private Universities students 'towards learning English and examine student's awareness of the assortment of English.

4. To study Private Universities students' attitudes towards the current learning English process and practice.

5. To present the factors that might have impacts on students towards learning English.

\section{Purpose of the study}

The main purpose of this research to investigate students' attitudes towards learning English and provide education providers with insights into students' attitudes towards 
learning English and the development of positive student attitude so that they can give more importance to the students' requirements and interests in learning English and facilitate their achievements.

\section{Statement of the problem}

As for the students learning English as a foreign language in Private Universities, it is significant that students have positive attitudes towards the target language, which is English. Othman et al. (2019) proved that positive attitude is correlated with success in learning English and high level of student's attitude will generate more effective language learners. In addition, second language learners get advantages from positive attitudes which lead to successful accomplishment of proficiency, on the other hand negative attitude of students will lead to decrease motivation and unsuccessful accomplishment of proficiency (Khan \& Abdullah, 2019). Therefore, the researcher points out the main research problem are that students in Private Universities are not encouraged and they have negative attitudes towards learning English. Students at Private Universities feel they are forced to learn English (Ali, 2020). This is one the factors which lead to decrease effectiveness and result in inefficient language learning. Many students in the Kurdistan region of Iraq have difficulties in learning English language due to the lack of motivation which leads to negative attitude towards learning English resulting inefficient language learning (Othman et al. 2019). Currently, the problem is whether students are willing or unwilling to learn English. It is important to show whether there is a statistically significant difference between students' attitudes towards learning English and their gender or their years of study (Andavar et al. 2020).

\section{Research Questions}

- What are the factors that have impacts on students' attitudes towards learning English in Private Universities?

- Is there a correlation between emotional, behavioural and cognitive aspects towards learning English as a second language?

- Is there a statistical difference between male and female students' attitudes towards learning English in Private Universities?

- Is there a statistical difference between students' attitudes towards learning English in Private Universities and the years of study?

\section{Research Hypotheses}

The addressed hypotheses for this research are:
H1: Students have negative attitudes towards learning English in terms of emotional behavioural and cognitive aspects.

H2: There is a statistically significant difference in Private Universities students' attitudes towards learning English language by gender.

H3: There is a statistically significant difference between the attitudes of Private Universities students towards learning English language and the years of their study.

H4: There is a correlation between emotional, behavioural and cognitive aspects towards learning English as a second language.

\section{LITERATURE REVIEW}

Attitude is considered to be one of the key factors one of the key successes for language learning, therefore several research studies have been conducted in the field of students' attitudes towards learning language (Anwar, 2017). Anwar, (2016) discussed the significant relation between the nature student and the importance of language use. Though, information regarding the language attitudes of students in Northern Iraq is not sufficient. Therefore, this research examines the students' attitudes towards learning English at universities in the Kurdistan region of Iraq. Attitude has several definitions from the perspective of diverse aspects and contexts. Abdulla et al. (2017) defined Attitude as person's belief regarding an attribute of executing the behaviour, prejudiced by assessments of attributes. Consequently, an individual has great belief that confidently valued consequences will outcome from. Anwar \& Balcioglu, (2016) defined attitude as connected to an individual's beliefs and values (Abdullah \& Abdul Rahman, 2015). The Macmillan English Dictionary (2002) defined the attitude as "somebody's thoughts or emotional state regarding to something, particularly as exposed in their behaviour (Faraj et al. 2021). All individuals have some attitudes towards everything, it could be negative or positive therefore, pupils' attitudes towards learning English will not vary with mentioned statement, pupils could have negative attitudes towards learning English language on the other hand they could have positive attitudes towards the English language (Hameed \& Anwar, 2018). According to Damit et al. (2019), attitude is a complex psychological construct. According to Anwar \& Ghafoor, (2017), There are many factors that play a role in students' success, and attitude is considered as one of the most influential factors. Also, teachers' attitude plays a role in teaching English language such as teachers' commitment and motivation (Prabhu et al. 2020). According to Anwar \& Climis, (2017), Students' attitude to the language is one of the personal variables that affect the learning of English language. Prabhu et al. (2019), 
pointed out that attitude consist of three components: cognitive, affective and behavioural. The cognitive component includes the thoughts regarding the object of the attitude. The affective component is related to the individual's emotions and feelings towards an object, and the behavioural component contains the propensity to accept specific learning behaviours (Ali, 2016). Anwar \& Qadir, (2017) defined the attitude as "an implication created on the basis of a compound of beliefs about the attitude object". Abdullah \& Rahman, (2015), argued the possibility of the three attitude components are so strictly interconnected. According to Van Els et al. (1984) discussed that no matter if three components or only. The link between all components is so strict that sufficient information on attitudes could be achieved by evaluating only a component. Abdullah, (2019) stated that language learning is linked to individual's attitude towards the target language. Anwar \& Louis, (2017) mentioned that positive language attitudes will have positive effects on learner to have positive direction towards learning language. Positive attitude will play positive role in learning language (Ali, 2014), also will be the main key for success concerning learning language (as stated by (Ali \& Anwar, 2021).

\section{Attitude towards Language Learning}

According to Khan \& Abdullah, (2019) several social and psychological features and attitude of learning the language towards second language impact the capability of the learners. Baker concentrated on the significance of the study regarding the impact of attitude on learning language (Anwar \& Abdullah, 2021). According to Prabhu et al. (2020) argued the importance of affective component and its effect on learning language behaviour, the main reason the importance of affective component such us values, interests and attitude of pupils related to effect of future behaviour. This explains the main reason of paying attention to positive attitudes for pupils towards learning language because positive attitude will have positive impact on pupil's future learning (Ganeshkumar et al. 2019). According to Abdullah \& Afshar, (2019) Pupil's capability, strategy and attitude clarify their accomplishment for learning language. Abdullah \& Rahman, (2015) mentioned that the capability of the pupils to learn a second language does not only effect by the language and mental skills, nonetheless likewise on the pupils' attitudes and opinions to the aimed language. Also, they pointed that the perception of the attitude can improve the whole language learning process, inducing the environment of pupil's belief and behaviours to the target language, its community and culture, and also it would classify their propensity to obtain the target language. Ali et al. (2021) pointed a theoretical model, concentrating on the significance of accompanying attitudinal study in the field of learning language.
Abdullah, (2018) showed that language education providers, scholars and pupils should recognize that a positive attitude and positive motivation of pupils enable language learning. Therefore, in case if the pupil does not have the propensity and concentration in obtaining the target language to connect with others, in such case pupil will face a negative attitude and not be encouraged and excited in language learning. Consequently, pupil' attitudes might include in language learning, the reason is it might have the impact on their performance in obtaining the aimed language (Saleh et al. 2021). Othman \& Abdullah, (2016) explain the present matters, pedagogical consequences and new instructions in belief regarding the language learning comprising cognitive, cultural, personal factors, contextual, affective, and social among which attitudes have a significant affect. There are many studies regarding the attitude towards the altered languages (Abdullah \& Othman, 2016), to varieties of English and other languages (Abdullah \& Othman, 2021), on learners' belief regarding learning the target language (Abdullah \& Abdul Rahman, 2015).

Many features of language attitude towards learning a new language have been explored and examined(Anwar \& Abdullah, 2021) the following scholars have been studied different aspects of attitude and its impact on learning new language, for instance, Anwar \& Shukur, (2015), studied the relationship between strategy of learning language and pupil's attitude, Anwar \& Abd Zebari, (2015), attitude and belief regarding learning aimed language, Anwar \& Surarchith, (2015), attitudes towards learning language and language itself at tertiary and secondary stages, Anwar, (2017), using peers to learn English language as attitude aspect, Anwar, (2016), attitudes towards arguable practices between education providers and their pupils(Abdulla et al. 2017). Anwar \& Balcioglu, (2016) argued that the main objectives in educating pupils through contented and language combined learning models is to inspire learner's positive attitude towards the aimed language. Based on the above mentioned it clarifies whether the objectives have been accomplished or not (Hameed \& Anwar, 2018). Many decades ago, the studies of attitudes have been examined in different languages. Also, Anwar \& Ghafoor, (2017), mentioned that there are many views regarding language attitudes, at the present time the most common view is an integration of 10 older opinions. This theory proposes that attitude towards altered languages is not stable nevertheless always varying and therefore there is no specific determination regarding attitudes towards learning language (Anwar \& Climis, 2017).

\section{Aspects of Language Attitude}

According to Anwar \& Qadir, (2017), Learning process is considered as a positive amendment in the person's personality regarding the cognitive behavioural and 
emotional attitude, meanwhile when an individual has learned a particular matter, therefore, an individual starts to behave and think in various ways and person's belief has been distinguished. Moreover, beside cognitive method, the learning process also has psychological and social aspects (Anwar \& Louis, 2017). Anwar \& Abdullah, (2021) stated that attitude comprises three components; the first component is about the attitudes related to the cognitive component. This might include perception /belief regarding the situation or an object connected to the attitude. The second component is the evaluative component. This indicates that the situation/object connected to the attitude might produce dislike/like. The third component is related to the attitudes that have a behavioural component for instance; specific attitude tends to motivate pupils to accept specific learning behaviours (Anwar \& Abdullah, 2021).

\section{Cognitive Attitude}

This aspect contains the belief of the language learners in terms of the information that they can gain and their sympathetic in the process of language learning. The cognitive aspect could be categorized into four phases of linking the earlier information and the new information, producing new information, examining new information, and implementing the new information in different circumstances (Anwar \& Abdullah, 2021).

\section{Behavioural Aspect of Attitude}

The behavioural aspect determines the way an individual reacts and behaves in specific circumstances. In detail, the effective language learning improves the pupils to recognize themselves with the native English speakers and adopt or obtain numerous features of behaviours which describe the participants of the aimed language community. Anwar \& Shukur, (2015) proved that, an individual with positive attitude will result with the demonstration of positive behaviour towards learning new language. Such individuals are perceived to be extra enthusiastic problem solving, to obtain the knowledge and competencies valuable for day-to-day life and to motivate emotionally (Anwar \& Abd Zebari, 2015).

\section{Emotional Aspect of Attitude}

Anwar \& Surarchith, (2015) argued that, learning process consider as an emotional process. Usually, it effects by several emotional elements. Choy \&Troudi (2006), the education provider and his pupils involve in numerous emotional actions in it and diverse fruits of emotions are yield. Attitude could assist the pupils to show their feeling whether they dislike/like the matters or circumstances. It has been agreed that the internal emotion and feeling of learning new language affect their viewpoints and their attitude towards the aimed language (Anwar, 2017).

\section{METHODOLOGY}

The purpose of this research is to investigate student's attitudes towards learning English language. The purposes of methodology are to explain research methodology, clarify the procedures that used in this research, define the measurements used in planning the instrument, explain data collection, and to provide a clear clarification of the statistical method used in order to analyse data. A quantitative method used in order to analyse data gathered by the researcher.

\section{Design of the study}

The researcher used questionnaire in order to be able to analyze the current study. The questionnaire was divided into two sections, the first section consisted of demographic questions; starting with respondent's age, gender and years of study. The second part of questionnaire consisted of 26 questions regarding student's attitude towards learning the English language.

\section{Duration of the study:}

The researcher distributed questionnaires in hard copies in private Universities and particularly in the first and second years of the English department of Language College.

\section{Sampling Size and Target Population}

The aim of sample design is to clearly determine set of objectives, the sampling technique will be random sampling method, where all first- and second-year students in English department of the college of language in Private Universities will have equal chances of being selected for the sample. The English department currently has 214 students in first and second years. The population of this study will be 214 participants and the target population of this study is 138participants (as shown in the formula). The following formula presents the sample size calculation:

Sample size $=\frac{\mathrm{z}^{2} \times \mathrm{P} \times(1-\mathrm{P})}{\mathrm{c}^{2}}$

$\mathrm{Z}=\mathrm{Z}$ value (1.96 for $95 \%$ confidence level)

$\mathrm{p}=$ percentage picking a choice

$\mathrm{c}=$ confidence interval

Sample size $=\frac{(1.96)^{2} \times 0.5 \times(1-0.5)}{(0.05)^{2}}$

Sample size $=\frac{0.9604}{0.0025}$

Sample size $=384.16$

New sample size $=\frac{\text { Samplesize }}{1+\left\{\frac{\text { samplesize-1 }}{\text { population }}\right\}}$

New sample size $=\frac{384.16}{1+\left\{\frac{384.16-1}{214}\right\}}$

New sample size $=138$ participants

Instrument for measuring (scales) 
The questionnaire structured in the form of multiple-choice questions were designed by the researcher. The participants were asked to mark each item on five-point Likert scales. This research instruments were validated by earlier researchers to be appropriate for measuring student's attitude towards learning English language.

\section{DATA ANALYSIS AND RESULTS}

\section{Demographic analysis}

Table1: Age

\begin{tabular}{|l|c|c|c|c|}
\hline Age groups & $\begin{array}{c}\text { Frequen } \\
\text { cy }\end{array}$ & $\begin{array}{c}\text { Perce } \\
\text { nt }\end{array}$ & $\begin{array}{c}\text { Valid } \\
\text { Percent }\end{array}$ & $\begin{array}{c}\text { Cumulati } \\
\text { ve } \\
\text { Percent }\end{array}$ \\
\hline $18-20$ & 68 & 49.3 & 49.3 & 49.3 \\
\hline $20-22$ & 68 & 49.3 & 49.3 & 98.6 \\
\hline $\begin{array}{l}23 \text { and } \\
\text { above }\end{array}$ & 2 & 1.4 & 1.4 & 100.0 \\
\hline Total & 138 & 100.0 & 100.0 & \\
\hline
\end{tabular}

As seen in table (1) the frequency and percentage of respondent's age, based on the statistical results of SPSS program, the researcher found the following results; $49.3 \%$ of respondents from total of 136 respondents fall into group 18-20 years old, $49.3 \%$ of respondents from total of 136 respondents fall into group 20-22 years old and $1.4 \%$ of respondents from total of 136 respondents fall into group 23 years old and above.

Table 2: Gender

\begin{tabular}{|l|l|r|r|r|r|}
\hline $\begin{array}{l}\text { Gender } \\
\text { groups }\end{array}$ & $\begin{array}{r}\text { Frequen } \\
\text { cy }\end{array}$ & $\begin{array}{r}\text { Percen } \\
\mathrm{t}\end{array}$ & $\begin{array}{r}\text { Valid } \\
\text { Percent }\end{array}$ & $\begin{array}{c}\text { Cumulativ } \\
\text { e Percent }\end{array}$ \\
\hline Male & 71 & 51.4 & 51.4 & 51.4 \\
\hline Female & 67 & 48.6 & 48.6 & 100.0 \\
\hline Total & 138 & 100.0 & 100.0 & \\
\hline
\end{tabular}

As seen in table (2) the frequency and percentage of participant's gender in this study, according to SPSS program, the researcher was able to find out the following results; $51.4 \%$ of participants were male and $48.6 \%$ of participants were female.

Table 3 Year of study

\begin{tabular}{|l|r|r|r|r|}
\hline Year groups & Frequency & $\begin{array}{c}\text { Percen } \\
\mathrm{t}\end{array}$ & $\begin{array}{c}\text { Valid } \\
\text { Percent }\end{array}$ & $\begin{array}{r}\text { Cumulativ } \\
\text { e Percent }\end{array}$ \\
\hline 1st year & 74 & 53.6 & 53.6 & 53.6 \\
\hline 2nd year & 64 & 46.4 & 46.4 & 100.0 \\
\hline
\end{tabular}

\begin{tabular}{|l|l|l|l|l|}
\hline Total & 138 & 100.0 & 100.0 & \\
\hline
\end{tabular}

After analysing the demographic study, as for respondent's education level, the researcher found out the following results; $53.6 \%$ of respondents out of 136 were in the first year of the study and $46.4 \%$ of respondents out of 136 were in the second year of the study as shown in table (3).

\section{Data analysis}

\section{Comparison Male/Female}

It was found that the comparison between the male and female in terms of their attitude towards the native English teacher. Their attitudes towards native English teachers were found to be positive. When learners were asked whether they would prefer to have native English speaker, eight male students rated as 'disagree', 19 male students rated as 'neutral', 37 male students rated as 'agree' and seven male students rated as 'strongly agree'. In terms of the female students' attitude; three female students rated as 'strongly disagree', 12 female students rated as 'agree', 19 female students rated as 'neutral', 37 female students rated as 'agree' and three female students rated as 'strongly agree'. The mean of Male group is 3.61 and mean of Female group is 3.37 , this indicates that the majority of both groups were in agreement and preferred to have a native English teacher. The comparison between the male and female students' attitude towards motivation to speak in English. Male students' attitudes were found to be negative whereas female students' attitudes were found to be positive. When learners were asked whether their teachers motivated them to speak in English, 10 male students rated as 'strongly disagree', 34 male students rated as 'disagree', 17 male students rated as 'neutral' and 10 male students rated as 'agree'. As for female students' attitude; six female students rated as 'strongly disagree', 16 female students as 'disagree', 12 female students rated as 'neutral', 25 female students rated as 'agree' and eight female students rated as 'strongly agree'. The mean of the male group is 2.38 . This indicates that the majority of male students rated as 'disagree' as to whether they were motivated by their teachers to speak in English. The mean of the female group is 3.19 , which indicates that the majority of female students rated as 'agree' concerning teacher's motivation to speak in English. According to the above results we can see the difference students' attitudes towards their teachers and its motivation. The comparison between the male and female students' attitude towards their engagement in dialogues. The attitudes of male students were found to be negative. When learners were asked whether their teachers engage them in dialogues for the practice of speaking skills: six male students rated as 'strongly', 30 male students rated as 'disagree', 21 male students rated as 'neutral' and 14 male students rated as 
'agree'. As for female students' attitude; three female students rated as 'strongly disagree', 21 female students rated as 'disagree' in, 14 female students rated as 'neutral', 25 female students rated as 'agree' and 4 female students rated as 'strongly agree'. The mean of the male group is 2.61 , which means that most of male students rated as 'disagree' in about the engagement of students in dialogues by their teacher for practising speaking skill. The mean of female group is 3.09 , which means that most of female students rated as 'agree' in terms of students' engagement in dialogues by their teacher for practising speaking skill. This shows the difference between male and female students' attitudes towards their engagement in dialogues by their teacher for practising speaking skill. As a result, it can be said that female students are engaged more in dialogues by their teacher for practising speaking skill. The attitudes of the male and female students towards the native English teachers were found to be negative as they thought those teachers were the source of difficulty. When learners were asked whether native English teachers make it more difficult to practise the English-speaking skills: eight male students rated as 'strongly disagree', 28 male students rated as 'disagree', 21 male students rated as 'neutral', 14 male students rated as 'agree'. As for the female students' attitude; three female students rated as 'strongly disagree', 20 female students rated as 'disagree', 16 female students rated as neutral, 25 female students rated as 'agree' and three female students rated as 'strongly agree'. The mean of male group is 2.58 whereas the mean of female group is 3.07 . This indicates that the majority of the male students rated as 'disagree' while the greatest part of female students rated as 'agree'. This means that the male and female students' attitudes towards the same are different. Moreover, it was found that both male and female students prefer to study English. As for the distribution of students' answers; four male students rated as 'disagree', 17 male students rated as 'neutral', 28 male students rated as 'agree' and 22 male students rated as 'strongly agree'. As for the female students; two female students rated as 'strongly disagree', eight female students rated as 'disagree', 20 female students rated as 'neutral', 24 female students rated as 'agree' and 13 female students rated as 'strongly agree'. The mean of male group is 3.96, which indicates that the majority of male students rated as 'agree' as to whether they prefer to study English. The mean of the female group is 3.57. This indicates that the majority of female students rated as agree. In other words, female students also prefer studying English to studying another language. The comparison between the male and female student's attitude towards the desirable of English subject were found to be positive. When learners were asked whether they prefer English subject than other subjects: four male students rated as 'disagree', 21 male students rated as 'neutral', 27 male students rated as 'agree' and 19 male students rated as 'strongly agree'. In terms of the female students' attitude; six female students rated as 'disagree', 13 female students rated as 'neutral', 26 female students rated as 'agree' and 22 female students rated as 'strongly agree'. The mean of male groups is 3.86 this indicates that the majority of male students rated as 'agree' concerning student's attitude towards the desirable of English subject comparing with other subjects and the mean of female group is 3.96 this indicates that the majority of female students rated as 'agree' concerning student's attitude towards the desirable of English subject comparing with other subjects. The comparison between the male and female students' attitude towards learning Standard English were found to be negative. When learners were asked whether their teachers teach them how to write Standard English: five male students rated as 'strongly disagree', 31 male students rated as 'disagree', 27 male students rated as 'neutral' and eight male students rated as 'agree'. in terms of the female students' attitude: five female students rated as 'strongly disagree', 21 female students rated as 'disagree', 20 female students rated as 'neutral', 16 female students rated as 'agree' and five female students rated as 'strongly agree'. The mean of male group is 2.54 this means that most of male students rated as 'disagree' concerning student's attitude towards learning standard English writing by their teacher, and the mean of female group is 2.93 this means that most of female students rated as 'disagree' concerning student's attitude towards learning standard English writing by their teachers as well. The comparison between the male and female students' attitude towards students' discussion and participation were found to be negative. When learners were asked whether their teachers allow them to discuss and ask any ambiguities in English: seven male students rated as 'strongly', 31 male students rated as 'disagree', 20 male students rated as 'neutral' towards allowing students to participate in class discussion, 13 male students as 'agree'. seven female students rated as 'strongly disagree', 28 female students rated as 'disagree', 22 female students rated as 'neutral' and 10 female students rated as 'agree'. The mean of male group is 2.55 this means that many of male students rated as 'disagree' towards allowing students to participate in class discussion and the mean of female group is 2.52 this means that many of female students rated as 'disagree' towards allowing students to participate in class discussion. The comparison between the male and female students' attitude towards feeling were found to be negative, when learners were asked whether they feel shy to practice their English skills in class discussions: two male students rated as 'disagree', 2 male students rated as neutral, 51 male students rated as 'agree' and 12 male students rated as 'strongly agree'. In terms of the female students' attitude; six 
female students rated as 'disagree' regarding, 15 female students rated as 'neutral', 41 female students rated as 'agree' and nine female students rated as 'strongly agree'. The mean of male group is 4.09 this means that the majority of male students rated as 'agree' regarding feeling shy while practising English skill in class discussion and the mean of female group is 3.75 this means that the majority of female students rated as 'agree' regarding feeling shy while practising English skill in class discussion. The comparison between the male and female students' attitude towards feeling comfortable were found to be negative for the male students and to be positive for the female students. When learners were asked whether their teachers make them comfortable to participate in class discussions: five male students rated as 'strongly disagree', 25 male students rated as 'disagree', 31 male students rated as 'neutral', 10 male students rated as 'agree'. 19 female students rated as 'disagree', 28 female students rated as 'neutral' and 29 female students rated as 'agree' regarding. The mean of male group is 2.65 this indicates that the majority of male students rated as 'disagree' towards feeling comfortable in class participation by their teacher while the mean of female group is 3.01 this indicates that the majority of female students rated as 'agree' towards feeling comfortable in class participation by their teacher.

Table 4 The comparison between Male and Female students

\begin{tabular}{|c|c|c|c|c|c|c|c|c|c|}
\hline \multicolumn{10}{|c|}{ I prefer native English teacher } \\
\hline \multicolumn{2}{|c|}{ Groups } & 1 & 2 & 3 & 4 & 5 & Total & Mean & Std. Deviation \\
\hline \multirow[t]{2}{*}{ Q1 } & Male & - & 8 & 19 & 37 & 7 & 71 & 3.61 & 0.819 \\
\hline & Female & 3 & 12 & 12 & 37 & 3 & 67 & 3.37 & 0.982 \\
\hline \multicolumn{10}{|c|}{ My teacher motivates me to speak in English } \\
\hline \multicolumn{10}{|c|}{ Comparison Male/Female } \\
\hline & Groups & 1 & 2 & 3 & 4 & 5 & Total & Mean & Std. Deviation \\
\hline \multirow[t]{2}{*}{ Q2 } & Male & 10 & 34 & 17 & 10 & - & 71 & 2.38 & .900 \\
\hline & Female & 6 & 16 & 12 & 25 & 8 & 67 & 3.19 & 1.196 \\
\hline \multicolumn{10}{|c|}{ My teacher engages us in dialogues for the practice of speaking skills. } \\
\hline \multicolumn{10}{|c|}{ Comparison Male/Female } \\
\hline & Groups & 1 & 2 & 3 & 4 & 5 & Total & Mean & Std. Deviation \\
\hline \multirow[t]{2}{*}{ Q3 } & Male & 6 & 30 & 21 & 14 & - & 71 & 2.61 & 0.902 \\
\hline & Female & 3 & 21 & 14 & 25 & 4 & 67 & 3.09 & 1.055 \\
\hline \multicolumn{10}{|c|}{ Native English teacher makes more difficult for me to practise my English-speaking skills } \\
\hline \multicolumn{10}{|c|}{ Comparison Male/Female } \\
\hline & Groups & 1 & 2 & 3 & 4 & 5 & Total & Mean & Std. Deviation \\
\hline \multirow[t]{2}{*}{ Q4 } & Male & 8 & 28 & 21 & 14 & - & 71 & 2.58 & 0.936 \\
\hline & Female & 3 & 20 & 16 & 25 & 3 & 67 & 3.07 & 1.020 \\
\hline \multicolumn{10}{|c|}{$\begin{array}{l}\text { I prefer English to the other languages } \\
\text { Comparison Male/Female }\end{array}$} \\
\hline & Groups & 1 & 2 & 3 & 4 & 5 & Total & Mean & Std. Deviation \\
\hline \multirow[t]{2}{*}{ Q5 } & Male & - & 4 & 17 & 28 & 22 & 71 & 3.96 & 0.885 \\
\hline & Female & 2 & 8 & 20 & 24 & 13 & 67 & 3.57 & 1.033 \\
\hline \multicolumn{10}{|c|}{ I prefer English subject than other subjects } \\
\hline \multicolumn{10}{|c|}{ Comparison Male/Female } \\
\hline & Groups & 1 & 2 & 3 & 4 & 5 & Total & Mean & Std. Deviation \\
\hline Q6 & Male & - & 4 & 21 & 27 & 19 & 71 & 3.86 & 0.883 \\
\hline
\end{tabular}




\begin{tabular}{|c|c|c|c|c|c|c|c|c|c|}
\hline & Female & - & 6 & 13 & 26 & 22 & 67 & 3.96 & 0.944 \\
\hline \multicolumn{10}{|c|}{ My teacher teaches me how to write standard English } \\
\hline \multicolumn{10}{|c|}{ Comparison Male/Female } \\
\hline & Groups & 1 & 2 & 3 & 4 & 5 & Total & Mean & Std. Deviation \\
\hline \multirow[t]{2}{*}{ Q7 } & Male & 5 & 31 & 27 & 8 & 0 & 71 & 2.54 & 0.790 \\
\hline & Female & 5 & 21 & 20 & 16 & 5 & 67 & 2.93 & 1.078 \\
\hline \multicolumn{10}{|c|}{$\begin{array}{l}\text { My teacher allows me to discuss and ask any ambiguities in English } \\
\text { Comparison Male/Female }\end{array}$} \\
\hline & Groups & 1 & 2 & 3 & 4 & 5 & Total & Mean & Std. Deviation \\
\hline \multirow[t]{2}{*}{ Q8 } & Male & 7 & 31 & 20 & 13 & - & 71 & 2.55 & 0.907 \\
\hline & Female & 7 & 28 & 22 & 10 & - & 67 & 2.52 & 0.877 \\
\hline \multicolumn{10}{|c|}{$\begin{array}{l}\text { I feel shy to practice my English skills in class discussions } \\
\text { Comparison Male/Female }\end{array}$} \\
\hline & Groups & 1 & 2 & 3 & 4 & 5 & Total & Mean & Std. Deviation \\
\hline \multirow[t]{2}{*}{ Q9 } & Male & - & 2 & 2 & 51 & 12 & 67 & 4.09 & 0.570 \\
\hline & Female & - & 6 & 15 & 41 & 9 & 71 & 3.75 & 0.788 \\
\hline \multicolumn{10}{|c|}{ My teacher makes me comfortable to participate in class discussions } \\
\hline \multicolumn{10}{|c|}{ Comparison Male/Female } \\
\hline & Groups & 1 & 2 & 3 & 4 & 5 & Total & Mean & Std. Deviation \\
\hline \multirow[t]{2}{*}{ Q10 } & Male & 5 & 25 & 31 & 10 & - & 71 & 2.65 & 0.812 \\
\hline & Female & - & 19 & 28 & 29 & - & 67 & 3.01 & 0.769 \\
\hline
\end{tabular}

\section{Correlation Analysis}

Table 5: Factor analysis

\begin{tabular}{|l|l|l|l|}
\hline Factor & Questions & $\begin{array}{l}\text { Factor } \\
\text { loading\% }\end{array}$ & $\begin{array}{l}\text { Number of } \\
\text { items }\end{array}$ \\
\hline Cognitive & $\begin{array}{l}\text { My teacher teaches me how to write standard English } \\
\text { My teacher engages us in dialogues for the practice of } \\
\text { speaking skills. } \\
\text { I prefer to be taught only in English }\end{array}$ & .912 & .904 \\
Behavioural & $\begin{array}{l}\text { I prefer to learn English to carry my tasks more } \\
\text { efficiently } \\
\text { I prefer English language than other languages } \\
\text { I prefer English subject than other subjects }\end{array}$ & .482 & .274 \\
\hline Emotional & $\begin{array}{l}\text { I improve my reading skills by reading English } \\
\text { newspapers or magazines } \\
\text { I improve my English skills by watching English } \\
\text { movies or series } \\
\text { I improve my listening skills by listening to English } \\
\text { Radio } \\
\text { I cannot memorize English words }\end{array}$ & .882 & .900 \\
\hline
\end{tabular}

Extraction Method: Principal Component Analysis 
Factor analysis determines essential variables that clarify the outline of associations within a set of perceived variables. Factor analysis is frequently used in reducing data to classify a small number of variables that clarify most of the variance perceived in greater number of visible variables. Table (5) indicates that the cognitive factor has three items, behavioural factor also has three items and emotional factor has four items.

Table 6 Correlation analysis cognitive, behavioural and emotional factors

\begin{tabular}{|c|c|c|c|c|}
\hline & & Cognitive & Behavioural & Emotional \\
\hline Cognitive & $\begin{array}{l}\text { Pearson Correlation } \\
\text { Sig. (2-tailed) } \\
\text { N }\end{array}$ & $\begin{array}{r}1 \\
138\end{array}$ & $\begin{array}{r}-.249^{* *} \\
.003 \\
138\end{array}$ & $\begin{array}{r}-.330{ }^{* *} \\
.000 \\
138\end{array}$ \\
\hline Behavioural & $\begin{array}{l}\text { Pearson Correlation } \\
\text { Sig. (2-tailed) } \\
\text { N }\end{array}$ & $\begin{array}{r}-.249^{* *} \\
.003 \\
138\end{array}$ & $\begin{array}{r}1 \\
138 \\
\end{array}$ & $\begin{array}{r}.336^{* *} \\
.000 \\
138\end{array}$ \\
\hline Emotional & $\begin{array}{l}\text { Pearson Correlation } \\
\text { Sig. (2-tailed) } \\
\text { N }\end{array}$ & $\begin{array}{r}-.330^{* *} \\
.000 \\
138\end{array}$ & $\begin{array}{r}.336^{* *} \\
.000 \\
138\end{array}$ & $\begin{array}{r}1 \\
138\end{array}$ \\
\hline
\end{tabular}

In Table 6, the correlational analysis presents the values of the identified correlation tests. The strength of the relationship between variables are determined by the correlational analysis. According to the correlation test, the cognitive factor has negative correlation ( $r=.-249^{* *}$, $\mathrm{p}<0.01$ ) with the behavioural factor. The negative linear relationship between cognitive and behaviours is moderately strong. The cognitive factor has a negative correlation $\left(r=.-.330^{* *}, \mathrm{p}<0.01\right)$ with the Emotional. The negative linear relationship between cognitive and Emotional factors is moderately strong. The Behavioural factor has a negative correlation $\left(r=.-336^{* *}, \mathrm{p}<0.01\right)$ with the Emotional. The negative linear relationship between the Emotional and behavioural factors is moderately strong.

\section{DISCUSSION}

\section{Comparisons Male/female:}

The research seeks to answer the question whether students have positive attitude towards learning English and whether the attitude varies in terms of gender. The conclusion deriving from the study is as follows:

\section{Positive attitude of male students}

The majority of male students would prefer to have a native English teacher. The majority of male students preferred English language other than other languages. The majority of male students preferred English subject comparing with other subjects. The most of male students are able to memorize English words. The greatest parts of male students are interesting English material. The greatest parts of male students are improving their English skills by listening to English radio. The greatest parts of male students are improving their reading skills by reading English newspaper and magazines. The greatest parts of male students are improving their English skills by watching English movies or series. The greatest parts of male students are memorizing English words by pictures. The greatest part of male students would prefer to be taught only in English. The greatest parts of male and female students do not prefer to be taught in English and Kurdish at the same time. The greatest part of male students rated would like to learn English to carry their tasks more efficiently. The greatest part of male students stated that teaching English starts at first grade.

\section{Positive attitude of female students:}

The majority of female students would prefer to have a native English teacher. The majority of female students stated that their teachers motivate them to speak in English. Most of female students stated that that their teachers encourage them to be engaged in practising speaking skills. The greatest part of female students stated that native English teachers will facilitate learning English language. The majority of male students preferred English language other than other languages. The majority of female students preferred English subject comparing with other subjects. 
The majority of female students are feeling comfortable in class participation by their teacher. The greatest parts of female students are interesting English homework. The greatest parts of female students are interesting English material. The greatest parts of female students are interesting in class activities. The greatest parts of female students are improving their English skills by listening to English radio. The greatest parts of female students are improving their reading skills by reading English newspaper and magazines. The greatest parts of female students are improving their English skills by watching English movies or series. The greatest parts of male and female students are memorizing English words by pictures. The greatest parts of female students would prefer to be taught only in English. The greatest parts of female and female students do not prefer to be taught in English and Kurdish at the same time.The greatest part of female students rated would like to learn English to carry their tasks more efficiently. The greatest part of female students stated that teaching English starts at first grade.

\section{Negative attitude of male students:}

The majority of male students stated that their teachers do not motivate them to speak in English. Most of male students stated that their teachers do not encourage them to be engaged in practising speaking skills. The greatest part of male students stated that native English teacher will not facilitate learning English language. The most of male students stated that their teachers do not teach them learning standard English.Many of female students stated that their teachers do not allow them to participate in class discussion. The majority of male students are feeling shy while practising English skill in class discussions. The majority of male students are not feeling comfortable in class participation by their teacher. The greatest parts of male students are interesting not English homework. The greatest parts of male students are not interesting in class activities. The greatest part of male students stated that their teachers are not organizing class activities in a proper way.

\section{Negative attitude of female students}

The most of female students stated that their teachers do not teach them learning standard English. Many of female students stated that their teachers do not allow them to participate in class discussion. The majority of female students are feeling shy while practising English skill in class discussion. Many of female students are not able to memorize English words. The greatest part of female students stated that their teachers are not organizing class activities in a proper way.

\section{Comparison first/ second year}

The research seeks to answer the question of student's attitude towards learning English language does it differ between first and second year of university, after analysing data the researcher came to conclude;

\section{Positive attitude of first year students:}

The greatest part of first year students would like to imitate native speaker. The greatest part of first year students would prefer to consider English language as a official language in Northern Iraq. The majority of first year students agreed and preferred to have a native English teacher. The majority of first year students stated that their teachers motivate them to speak in English. Most of first year students stated that their teachers engage them in dialogues for practising speaking skill. The greatest part of first year students stated that native teachers will facilitate their English speaking skill. The majority of first year students would prefer English language comparing to other languages. The majority of first year students prefer English subject comparing with other subjects. The greatest part of first year students are interesting English material. The greatest part of first year students are improving their English skills by listening to English radio. The greatest part of second year students are improving their reading skills by reading English newspaper and magazines. The greatest part of first year students are improving their English skills by watching English movies or series. The greatest part of first year students are memorizing English words by pictures. The greatest part of first year students would like to be taught only in English. The greatest part of first year students rated are learning English to carry their tasks more efficiently. The greatest part of first year students stated that teaching English starts at first grade. The greatest part of first year students are able and willing to imitate native speaker.

\section{Positive attitude of second year students:}

The greatest part of second year students would prefer to consider English language as an official language in Northern Iraq. The majority of second year students agreed and preferred to have a native English teacher. The majority of second year students would prefer English language comparing to other languages. The majority of second year students prefer English subject comparing with other subjects. Most of second year students are able to memorize English words. The greatest part of second year students are interesting English homework. The greatest part of second year students are interesting English material. The greatest part of second year students are interesting in class activities. The greatest part of first year students is improving their English skills by listening to English radio. The greatest part of second year students is improving their reading skills by reading English newspaper and magazines. The greatest part of second year students is improving their English skills by watching English movies or series. The greatest part of second year students is memorizing English 
words by pictures. The greatest part of first year students would like to be taught only in English. The greatest part of second year students rated are learning English to carry their tasks more efficiently. The greatest part of second year students stated that teaching English starts at first grade. The greatest part of second year students is able and willing to imitate native speaker. The greatest part of second year students would like to imitate native speaker.

\section{Negative attitude of first year students}

Most of first students stated that their teachers do not show the direction of learning Standard English writing. Many of first year students stated that their teachers do not allow them to participate in class discussion. The majority of second year students are feeling shy while practising English skill in class discussion. The majority of first year students are not feeling comfortable in class participation by their teacher. Most of first year students are not able to memorize English words. The greatest part of first year students are not interesting English homework. The greatest parts of fist year students are not interesting in class activities. The greatest part of second year students stated that their teachers do not organize their class activities in a proper way. The greatest part of first year students is getting confused when teacher teaches students in English and Kurdish at the same time.

\section{Negative attitude of second year students}

The majority of second year students stated that their teachers do not motivate them to speak in English. Most of first year students stated that their teachers do not engage them in dialogues for practising speaking skill. The greatest part of second year students stated that native teachers will not facilitate their English-speaking skill. Most of second students stated that their teachers do not show the direction of learning Standard English writing. Many of second year students stated that their teachers do not allow them to participate in class discussion. The majority of second year students are feeling shy while practising English skill in class discussion. The majority of second year students are not feeling comfortable in class participation by their teacher. The greatest part of second year students stated that their teachers do not organize their class activities in a proper way. The greatest part of second year students is getting confused when teacher teaches students in English and Kurdish at the same time.

\section{Correlation analysis}

According to the correlation test, it has been found out that cognitive has negative correlation $\left(r=.-.249^{* *}, p<0.01\right)$ with Behaviour. Concerning the negative of the linear relationship is moderately strong between cognitive and behaviour, cognitive has negative correlation $\left(\mathrm{r}=.-.330^{* *}\right.$, $\mathrm{p}<0.01)$ with Emotional. Concerning the negative of the linear relationship is moderately strong between cognitive and Emotional, and Behavioural has negative correlation $\left(r=.-336^{* *}, p<0.01\right)$ with Emotional. Concerning the negative of the linear relationship is moderately strong between Emotional and behaviour, therefore hypotheses four supported.

\section{CONCLUSION}

Many students have negative attitudes towards English. This indicates that students are not aware of the significance of the English language. 'Attitude' is considered as a necessary factor in language learning. Therefore, it is important to create a positive atmosphere in English classes to develop positive attitude in learners. University lecturers should take account of the beliefs, feelings and behaviours of the learners of English. Students' attitudes significantly vary with respect to their gender and the years of language education that they have had. This evidently emphasizes the need for particular attention in this area. Based on the statistical results, the researcher came to the conclusion that current students have negative attitude towards the learning English language; therefore, the first hypothesis is supported. As it can be seen in the following tables, the comparison of male attitudes towards learning English with those of females indicates the significant difference between the two. Thus, it can be stated that the second hypothesis is supported.

\section{Recommendations}

Concerning the negative attitude towards learning English, the university lecturers are recommended to establish a motivating feeling in the learners of English to promote the students' positive attitudes towards learning English. Lecturers also should highlight the significance of learning English. This could be attained by applying proper activities and methods of teaching English effectively. Moreover, lecturers should provide students with recent English materials additionally to their English books. This will aid lecturers in attracting students' attention to learning English effectively. Furthermore, university lecturers should take into their consideration the role of gender in language learning, verifying their methods of teaching to enhance students' attitude and motivation. Considering the results of the study:

- It is recommended that lecturers should teach Standard English to the English language learners.

- Lecturers should motivate and allow students to participate in class discussions.

- Lecturers should provide a positive and comfortable class environment, so students will 
feel more relaxed to practise their English skill in class discussion.

- Lecturers should also organize appropriate class activities.

\section{REFERENCES}

[1] Tsunemoto, A., \& McDonough, K. (2020). Exploring Japanese EFL learners' attitudes toward English pronunciation and its relationship to perceived accentedness. Language and speech, 0023830919900372.

[2] Kaba, A., \& Abdullah, A. D. (2020). Investigating Students' Attitudes Toward Arabic and English Textbooks in Communication and Media. SAGE Open, 10(3), 2158244020949208.

[3] Namaziandost, E., Ziafar, M., \& Neisi, L. (2020). Students' attitudes toward flipped classroom model: Focusing on Iranian advanced EFL learners. English Language Teaching and Research Journal (ELTAR-J), 2(1), 16-26.

[4] Abdullah, N. N., \& Othman, M. B. (2019). Effects of Intellectual Capital on the Performance of Malaysian Food and Beverage Small and Medium-Sized Enterprises. International Journal of Civil Engineering and Technology (IJCIET), 10(2), 135-143

[5] Anwar, G., \& Abdullah, N. N. (2021). Inspiring future entrepreneurs: The effect of experiential learning on the entrepreneurial intention at higher education. International Journal of English Literature and Social Sciences, 6.

[6] Gardi, B., Hamawandy, N. M., Vian Sulaiman Hama Saeed, R. M. A., Sulaiman, A. A., Mahmood, S. A., \& Al-Kake, F. A. (2020). The Effect of Capital Competence on the Profitability of Development and Investment Banks in Turkey. Solid State Technology, 63(6), 12571-12583.

[7] Prabhu, M., Nambirajan, T., \& Abdullah, N. N. (2020). Operating competitive priorities of manufacturing firms: An analytical study. Journal of Industrial Engineering and Management, 13(1), 38-55 .

[8] Anwar, G., \& Shukur, I. (2015). The Impact of Training and Development on Job Satisfaction: A Case Study of Private Banks in Erbil. International Journal of Social Sciences \& Educational Studies, 2(1), 65.

[9] Sultan, K., Ahmed, R. R., Jafar, R., Murtaza, M. M., \& Gardi, B. (2020). Corporate Financial Policy And Its Impact On Sustainable Capital Structure: Empirical Evidence From Textile Firms Of Pakistan.

[10] Abdullah, N. N., \& Othman, M. (2015). Disaster Management: Empirical Study of 2009 Jeddah Flood. Abdullah, NN \& Othman, M.(2015). Disaster Management: Empirical Study of, 1083-1087.

[11] Gardi, B. (2021). Investigating the effects of Financial Accounting Reports on Managerial Decision Making in Small and Medium-sized Enterprises. Turkish Journal of Computer and Mathematics Education (TURCOMAT), 12(10), 2134-2142

[12] Anwar, G., \& Shukur, I. (2015). Job satisfaction and employee turnover intention: A case study of private hospital in Erbil. International Journal of Social Sciences \& Educational Studies, 2(1), 73.
[13] Ismael, N. B., Sorguli, S., Aziz, H. M., Sabir, B. Y., Hamza, P. A., Gardi, B., \& Al-Kake, F. R. A. (2021). The Impact of COVID-19 on Small and Medium-Sized Enterprises in Iraq. Annals of the Romanian Society for Cell Biology, 24962505.

[14] Anwar, G., \& Shukur, I. (2015). the impact of recruitment and selection on job satisfaction: Evidence from private school in Erbil. International Journal of Social Sciences \& Educational Studies, 1(3), 4-13.

[15] Gardi, B. (2021). The effects of computerized accounting system on auditing process: a case study from northern Iraq. Available at SSRN 3838327

[16] Anwar, G., \& Abd Zebari, B. (2015). The Relationship between Employee Engagement and Corporate Social Responsibility: A Case Study of Car Dealership in Erbil, Kurdistan. International Journal of Social Sciences \& Educational Studies, 2(2), 45

[17] Anwar, G., \& Surarchith, N. K. (2015). Factors Affecting Shoppers' Behavior in Erbil, Kurdistan-Iraq. International Journal of Social Sciences \& Educational Studies, 1(4), 10.

[18] Othman, B. J., Al-Kake, F., Diah, M. L. M., Othman, B., \& Hasan, N. M. (2019). This study examines the antecedents and the effects of knowledge management and information technology in the manufacturing industry. International Journal of Psychosocial Rehabilitation, 23(02).

[19] Khan, S. \& Abdullah, N. N. (2019). The effect of ATM service quality on customer's satisfaction and loyalty: an empirical analysis. RJOAS, 5(89): DOI 10.18551/rjoas.2019-05.28

[20] Anwar, G., \& Shukur, I. (2015). The Impact of Service Quality Dimensions on Students' Satisfaction. International Journal of Social Sciences \& Educational Studies, 76.

[21] Othman, B. J., Al-Kake, F., Diah, M. L. M., Othman, B., Hussein, S., \& Hasan, N. M. (2019). Impact of the foreign direct investment on the economy of the United Kingdom. International Journal of Psychosocial Rehabilitation, 23(02).

[22] Anwar, K. (2017). Analyzing the conceptual model of service quality and its relationship with guests'satisfaction: A STUDY OF HOTELS IN ERBIL. The International Journal of Accounting and Business Society, 25(2), 1-16.

[23] Anwar, K. (2016). Comparison between cost leadership and differentiation strategy in agricultural businesses. Custos $\mathrm{E}$ Agronegocio on Line, 12(2), 212-231

[24] Abdullah, M. S., Toycan, M., \& Anwar, K. (2017). The cost readiness of implementing e-learning. CUSTOS E AGRONEGOCIO ON LINE, 13(2), 156-175.

[25] Anwar, K., \& Balcioglu, H. (2016). The relationship between transformational leadership characteristics and effectiveness: A case study of construction companies in Erbil. International Journal of Science Technology and Management, 5(2), 250-256.

[26] Abdullah, N. N., \& Abdul Rahman, M. (2015). The Degree of Openness in Turkey's Public Expenditure. International Journal of Administration and Governance, 12(1), 8-12.

[27] Anwar, K. (2017). The Role of Effective Leadership in Crisis Management: Study of Private Companies in Kurdistan. Qalaai Zanist Scientific Journal, 2(4), 326-338. 
[28] Hameed, A. A., \& Anwar, K. (2018). Analyzing the Relationship between Intellectual Capital and Organizational Performance: A Study of Selected Private Banks in Kurdistan. International Journal of Social Sciences \& Educational Studies, 4(4), 39.

[29] Damit, D. H. D. A., Harun, A., Martin, D., Othman, B., \& Ahmad, H. (2019). What makes a non-Muslim purchase halal food in a Muslim country? An application of theory of planned behaviour. Management Science Letters, 9(12), 2029-2038.

[30] Anwar, K., \& Ghafoor, C. (2017). Knowledge management and organizational performance: A study of private universities in Kurdistan. International Journal of Social Sciences \& Educational Studies, 4(2), 53.

[31] Prabhu, M., Thangasamy, N., \& Nawzad Abdullah, N. (2020). Analytical review on competitive priorities for operations under manufacturing firms. Journal of Industrial Engineering and Management, 13(1), 38-55.

[32] Anwar, K., \& Climis, R. (2017). Analyzing the relationship between types of advertisement and customer choice: a study of retailer stores in erbil. The International Journal of Accounting and Business Society, 25(2), 43-52.

[33] Anwar, K. (2017). Factors Affecting Stock Exchange Investment In Kurdistan. The International Journal of Accounting and Business Society, 25(1), 32-37

[34] Prabhu, M., Abdullah, N. N. \& Mohan, M. G. (2019). An Empirical Study on the Satisfaction Level of National and International Tourists towards Natural Attractions in Kurdistan. African Journal of Hospitality, Tourism and Leisure, 8 (2). 1-8

[35] Anwar, K., \& Qadir, G. H. A Study of the Relationship between Work Engagement and Job Satisfaction in Private Companies in Kurdistan. International Journal of Advanced Engineering, Management and Science, 3(12), 239944.

[36] Abdullah, NN \& Rahman, MFA (2015). The Use of Deliberative Democracy in Public Policy Making Process. Public Policy and Administration Research, 5(3), 221-229

[37] Anwar, K. Leading Construction Project Teams: The Effectiveness of Transformational Leadership in Dynamic Work Environments in Kurdistan. International Journal of Advanced Engineering, Management and Science, 3(10), 239925.

[38] Abdullah, N. N. (2019). Probing the Level of Satisfaction towards the Motivation Factors of Tourism in Kurdistan Region. Scholars Journal of Economics, Business and Management, 5 (6). 439-443.

[39] Anwar, K., \& Louis, R. (2017). Factors Affecting Students' Anxiety in Language Learning: A Study of Private Universities in Erbil, Kurdistan. International Journal of Social Sciences \& Educational Studies, 4(3), 160.

[40] Ali, B. J., \& Anwar, G. (2021). The Effect of Marketing Culture Aspects of Healthcare Care on Marketing Creativity. Ali, BJ, \& Anwar, G.(2021). The Effect of Marketing Culture Aspects of Healthcare Care on Marketing Creativity. International Journal of English Literature and Social Sciences, 6(2), 171-182.

[41] Ali, B. J., \& Anwar, G. (2021). An Empirical Study of Employees' Motivation and its Influence Job
Satisfaction. Ali, BJ, \& Anwar, G.(2021). An Empirical Study of Employees' Motivation and its Influence Job Satisfaction. International Journal of Engineering, Business and Management, 5(2), 21-30.

[42] Khan, S. I., \& Abdullah, N. N. (2019). The impact of staff training and development on teachers' productivity. Economics, Management and Sustainability, 4(1), 37-45.

[43] Ali, B. J., \& Anwar, G. (2021). The balanced scorecard's evolution as a strategic mechanism at banking sectors. Ali, BJ, \& Anwar, G.(2021). The Balanced Scorecard'S Evolution as a Strategic Mechanism at Banking Sectors. International Journal of English Literature and Social Sciences, 6(1), 471-478.

[44] Anwar, G., \& Abdullah, N. N. (2021). The impact of Human resource management practice on Organizational performance. International journal of Engineering, Business and Management (IJEBM), 5.

[45] Abdullah, N. N., \& Anwar, G. (2021). An Empirical Analysis of Natural Gas as an Alternative Fuel for Internal Transportation. International Journal of English Literature and Social Sciences, 6(1).

[46] Ali, B. J., \& Anwar, G. (2021). Factors Influencing the Citizens' Acceptance of Electronic Government. International journal of Engineering, Business and Management (IJEBM), 5.

[47] Anwar, G., \& Abdullah, N. N. (2021). Inspiring future entrepreneurs: The effect of experiential learning on the entrepreneurial intention at higher education. International Journal of English Literature and Social Sciences, 6.

[48] Prabhu, M., Abdullah, N.N., Ahmed, R.R. (2020). Segmenting the manufacturing industries and measuring the performance: using interval-valued triangular fuzzy TOPSIS method. Complex Intell. Syst.. https://doi.org/10.1007/s40747-020-00157-0

[49] Ali, B. J., \& Anwar, G. (2021). A study of knowledge management alignment with production management: A study of carpet manufacture in Kurdistan region of Iraq. Ali, BJ, \& Anwar, G.(2021). A Study of Knowledge Management Alignment with Production Management: a Study of Carpet Manufacture in Kurdistan Region of Iraq. International Journal of English Literature and Social Sciences, 6(2), 346-360

[50] Ganeshkumar, C., Prabhu, M., \& Abdullah, N. N. (2019). Business Analytics and Supply Chain Performance: Partial Least Squares-Structural Equation Modeling (PLS-SEM) Approach. International Journal of Management and Business Research

[51] Ali, B. J., \& Anwar, G. (2021). Business strategy: The influence of Strategic Competitiveness on competitive advantage. International Journal of Electrical, Electronics and Computers, 6(2).

[52] Abdullah, N. N. \& Afshar, P. A. (2019). Investigating research and development costs on the profitability of Iranian industries. Journal of Organizational Behavior Research. Volume 4 (S2). 1-14

[53] Ali, B. J., \& Anwar, G. (2021). Marketing Strategy: Pricing strategies and its influence on consumer purchasing 
decision. Ali, BJ, \& Anwar, G.(2021). Marketing Strategy: Pricing strategies and its influence on consumer purchasing decision. International journal of Rural Development, Environment and Health Research, 5(2), 26-39

[54] Abdullah, NN, \& Rahman, MFA (2015). Access to Government Information in Public Policy Making Process: A Case Study of Kurdistan. International Information Institute (Tokyo). Information, 18(8), 3447

[55] Ali, B. J., Saleh, P. F., Akoi, S., Abdulrahman, A. A., Muhamed, A. S., Noori, H. N., \& Anwar, G. (2021, May). Impact of Service Quality on the Customer Satisfaction: Case study at Online Meeting Platforms. In Ali, BJ, Saleh, Akoi, S., Abdulrahman, AA, Muhamed, AS, Noori, HN, Anwar, G.(2021). Impact of Service Quality on the Customer Satisfaction: Case study at Online Meeting Platforms. International journal of Engineering, Business and Management (Vol. 5, No. 2, pp. 65-77).

[56] Abdullah, N. N. (2018). Probing the Level of Satisfaction towards the Motivation Factors of Tourism in Kurdistan Region. 5(6), 439-443. DOI: 10.21276/sjebm.2018.5.6.3

[57] Ali, B. J., \& Anwar, G. (2021). Strategic leadership effectiveness and its influence on organizational effectiveness. International Journal of Electrical, Electronics and Computers, 6(2).

[58] Saleh, P. F., Ali, B. J., Akoi, S., Najmalddin, B., Ali, R. S., \& Anwar, G. (2021). Factors affecting the Success of Female Entrepreneurs in Kurdistan. International journal of Engineering, Business and Management (IJEBM), 5.

[59] Othman, M., \& Abdullah, N. N. (2016). The Conceptual Assessment of Malaysian Entrepreneurship Environment and EO Economic Contribution. Journal of Resources Development and Management, 20, 15-20.

[60] Ali, B. J., \& Anwar, G. (2021). Intellectual capital: A modern model to measure the value creation in a business. Ali, BJ, \& Anwar, G.(2021). Intellectual capital: A modern model to measure the value creation in a business. International journal of Engineering, Business and Management, 5(2), 31-43.

[61] Abdullah, N. N., \& Othman, M. (2016). The Contribution of Human Capital Investment in the Growth of East Asian Economy-A Literature Review. Journal of Economic and Business Research, 22(1), 190-203.

[62] Ali, B. J., \& Anwar, G. (2021). Organization citizenship behaviour as a determining Factor in Business outcome. Ali, BJ, \& Anwar, G.(2021). Organization citizenship behaviour as a determining Factor in Business outcome. International journal of Rural Development, Environment and Health Research, 5(2), 17-25.

[63] Abdullah, N. N., \& Othman, M. B. (2021). Investigating the Limitations of Integrated Tasks on Youth Entrepreneurship in Kurdistan Region. Путеводитель предпринимателя, 14(2), 179-190.

[64] Abdullah, N. N., \& Abdul Rahman, M. (2015). Chinese Economic Activities and Interests in Developing Countries. Australian Journal of Basic and Applied Sciences, 9(25), 7986.

[65] Ali, B. J., \& Anwar, G. (2021). The mediation role of change management in employee development. Ali, BJ, \& Anwar,
G.(2021). The Mediation Role of Change Management in Employee Development. International Journal of English Literature and Social Sciences, 6(2), 361-374.

[66] Top, C., \& Ali, B. J. (2021). Customer satisfaction in online meeting platforms: Impact of efficiency, fulfillment, system availability, and privacy. Amazonia Investiga, 10(38), 7081. https://doi.org/10.34069/AI/2021.38.02.7

[67] Demir, A., Maroof, L., Sabbah Khan, N.U. and Ali, B.J. (2020), "The role of E-service quality in shaping online meeting platforms: a case study from higher education sector", Journal of Applied Research in Higher Education. https://doi.org/10.1108/JARHE-08-2020-0253

[68] Ali, B, J. (2021). Impact of consumer animosity, boycott participation, boycott motivation, and product judgment on purchase readiness or aversion of Kurdish consumers in Iraq. Journal of Consumers Affaires; 1-20. https://doi.org/10.1111/joca. 12350

[69] Ali, B, J. (2020). Impact of COVID-19 on consumer buying behavior toward online shopping in Iraq. Economic studies journal. 18(42): 267-280. Retrieved from https://www.asjp.cerist.dz/en/article/134070

[70] Ali, B.J. (2021) Assessing (The impact) of advertisement on customer decision making: Evidence from an educational institution. Afak for sciences journal, 6(1): 425-439. Retrieved from https://www.asjp.cerist.dz/en/article/141056

[71] Ali, B.J. (2021) Consumer attitudes towards healthy and organic food in the Kurdistan region of Iraq. Management Science Letters. 11: 1-8. DOI: 10.5267/j.msl.2021.2.015

[72] Andavar, V., Ali, B.J., and Ali, S.A. (2020) Rainwater for Water Scarcity Management: An Experience of Woldia University (Ethiopia). Journal of Business, Economics and Environmental Studies, 10-(4): 29-34. DOI: 10.13106/jbees.2020.vol10.no4.29

[73] Faraj, K. M., Faeq, D. K., Abdulla, D. F., Ali, B. J., \& Sadq, Z. M. (2021). Total Quality Management And Hotel Employee Creative Performance: The Mediation Role Of Job Embeddedment. Journal of Contemporary Issues in Business and Government Vol, 27(1).

[74] Ali, B. J. (2016). Iraq Stock Market and its Role in the Economy. Retrieved from https://www.amazon.com/IraqStock-Market-Role-Economy/dp/3659634271

[75] Ali, B. J. (2014). Brand Building in the Consumer Electronics Industry in Iraq. Retrieved from https://www.amazon.com/Brand-Building-ConsumerElectronics-Industry/dp/6200248699

[76] Ali, B. J., \& Anwar, G. (2021). Capital Structure and Firm Profitability in Developing Countries. GOYA, 68(374), 163-174. Retrieved from https://goyajournal.org/index.php/goya/article/view/35

[77] Ali, B. J., \& Anwar, G. (2021). Factors Influencing the Citizens' Acceptance of Electronic Government. International Journal of Engineering, Business and Management, 5(1), 48-60. https://doi.org/10.22161/ijebm.5.1.5

[78] Ali, B. J., \& Anwar, G. (2021). The Effect of Marketing Culture Aspects of Healthcare Care on Marketing Creativity. International Journal of English Literature and Social 
Sciences, $\quad 6(2), \quad$ 171-182. https://doi.org/10.22161/ijels.62.25

[79] Ali, B. J., \& Anwar, G. (2021). An Empirical Study of Employees' Motivation and its Influence Job Satisfaction. International Journal of Engineering, Business and Management, 5(2), 21-30. https://doi.org/10.22161/ijebm.5.2.3

[80] Ali, B. J., \& Anwar, G. (2021). The balanced scorecard's evolution as a strategic mechanism at banking sectors. International Journal of English Literature and Social Sciences, $\quad 6(1), \quad 471-478$. https://doi.org/10.22161/ijels.61.63

[81] Ali, B. J., \& Anwar, G. (2021). Self-Leadership Skills as Intangible Resources for Sustainable Competitive Advantage. Gongcheng Kexue $\mathrm{Yu}$ Jishu/Advanced Engineering Science, 46(1), 88-104. Retrieved from https://gongcheng-

journal.com/index.php/AES/article/view/10

[82] Ali, B. J., \& Anwar, G. (2021). Health sector reform: A Change Management Perspective on Health sector Reform. Gongcheng Kexue Yu Jishu/Advanced Engineering Science, 46(2), 29-38. Retrieved from https://gongchengjournal.com/index.php/AES/article/view/13

[83] Ali, B. J., \& Anwar, G. (2021). Organizational Learning as A Determining Factor in Firm Performance. GOYA, 68(374), 193-202. Retrieved from https://goyajournal.org/index.php/goya/article/view/40 